\title{
Herbaceous Response to Cattle Grazing Following Juniper Cutting in Oregon
}

\author{
Jon D. Bates \\ Author is Rangeland Scientist, US Department of Agriculture-Agricultural Research Service (USDA-ARS), \\ Eastern Oregon Agricultural Research Center, 67826-A Hwy 205, Burns, OR 97720.
}

\begin{abstract}
The rapid expansion of western juniper (Juniperus occidentalis spp. occidentalis Hook.) across the northern Great Basin has diminished shrub and understory plant composition and reduced forage production. Juniper removal has accelerated during the past decade in Oregon and California to restore shrub-steppe plant communities. Livestock grazing can affect posttreatment successional dynamics, but these impacts have not received adequate study. This study evaluated herbaceous plant recovery in a cut western juniper woodland subjected to grazed and ungrazed prescriptions over 4 growing seasons. The study consisted of 4 treatments: ungrazed cut, grazed cut, ungrazed woodland, and grazed woodland. Stocking rates were 0.78 cow-calf pairs per ha for 5 days in the first year following treatment and 0.94 cow-calf pairs per ha for 4 days in the second year after treatment. The grazing portion of the study lacked true replication because grazed plots were not independent of each other (cattle had access to all plots simultaneously). This limits the strength and interpretation of the grazing results. Juniper cutting removed overstory interference and resulted in significant increases in herbaceous cover, biomass, and seed production when compared to adjacent woodlands. Herbaceous cover, standing crop, perennial grass density, and seed production all increased in the ungrazed cut treatment compared to ungrazed woodland. A similar level of response was measured in the grazed pasture where herbaceous responses were greater in the grazed cut vs. the grazed woodland. Grazing in the cut treatment did not limit herbaceous recovery except that perennial grass seed production was lower in the grazed cut than in the ungrazed cut. Rest or deferment is required the first several growing seasons after juniper cutting to provide plants the opportunity to maximize seed crops. These results imply that juniper cutting had a greater effect on herbaceous dynamics than did the grazing application.
\end{abstract}

\section{Resumen}

La expansión rápida del "western juniper" (Juniperus occidentalis spp. occidentalis Hook.) a través de la Gran Cuenca del Norte ha disminuido la composición de arbustos y plantas del estrato bajo ellos y reducido la producción vegetal. En Oregon y California, la remoción del "juniper" se ha acelerado durante la década pasada para reestablecer las comunidades esteparias de arbustos. El apacentamiento del ganado puede afectar la dinámica sucesional posterior al tratamiento, pero estos impactos no han sido estudiados adecuadamente. Este estudio evaluó la recuperación de plantas herbáceas en un bosque talado de "western juniper”, sujeto a apacentamiento y exclusión por cuatro estaciones de crecimiento. El estudio consistió en cuatro tratamientos: sin apacentamiento con tala, apacentamiento con tala, bosque sin apacentamiento y bosque con apacentamiento. La carga animal fue de 0.78 pares de vaca-cría por ha durante 5 días en el primer año posterior al tratamiento y 0.94 pares vaca-cría por ha durante cuatro días en el segundo año posterior al tratamiento. La porción de apacentamiento careció de repeticiones verdaderas porque las parcelas de apacentadas no fueron independientes una de otra (el ganado tuvo acceso simultáneamente a todas las parcelas). El lector debe tener en consideración que esto limita la fortaleza e interpretación de los resultados de apacentamiento. La tala del "juniper" removió la interferencia de la biomasa aérea y resultó en un incremento significativo de la cobertura, biomasa y producción de semilla de las herbáceas en comparación con bosques adyacentes. La cobertura herbácea, biomasa en pie, densidad de zacates perennes y producción de semilla se incrementaron en el tratamiento sin apacentamiento con tala comparado con el bosque sin apacentamiento. Un nivel similar de respuesta fue medido en los potreros apacentados, donde la respuesta de herbáceas fue mayor en apacentamiento y talado con respecto a bosque apacentado. El apacentamiento en el tratamiento de tala no limitó la recuperación de herbáceas, con excepción de que la producción de semilla de zacates perennes que fue inferior en el tratamiento de apacentamiento más tala que en el de tala sin apacentamiento. El descanso o diferimiento es requerido en las primeras estaciones de crecimiento después de que el "western juniper" es cortado para brindar a las plantas la oportunidad maximizar la producción de semilla. Los resultados implican que el corte del "western juniper" tuvo un mayor efecto en la dinámica de herbáceas que la aplicación de apacentamiento.

Key Words: bluebunch wheatgrass, Great Basin, Juniperus occidentalis, seed production, Stipa thurberiana, utilization

The Eastern Oregon Agricultural Research Center is jointly funded by USDA-ARS and by the Oregon Agricultural Experiment Station. Correspondence: Jon D. Bates, USDA-ARS, Eastern Oregon Agricultural Research Center, 67826-A Hwy 205, Burns, OR 97720. Email: jon.bates@oregonstate.edu

Manuscript received 9 May 2003; manuscript accepted 27 December 2004. 


\section{INTRODUCTION}

Western juniper (Juniperus occidentalis spp. occidentalis Hook. $)^{1}$ woodlands have expanded rapidly since the late 1800s in eastern Oregon, southwestern Idaho, and along the border region of northern California and Nevada (Miller and Tausch 2001). Juniper woodlands currently occupy 3.5 million ha in the northern Great Basin, of which $95 \%$ consists of postsettlement woodlands of 120 years or less in age (Miller and Rose 1995; Miller et al. 2000). Dominance by postsettlement juniper in mountain big sagebrush (Artemisia tridentata spp. vaseyana Nutt.) and other plant communities diminishes shrub-understory diversity and cover (Miller et al. 2000; Wall et al. 2001) and results in reduced forage productivity (Vaitkus and Eddleman 1987; Bates et al. 2000). Juniper dominance on shallow soils causes significant reductions in ground cover, thus increasing bare ground and increasing soil erosion potential (Buckhouse and Mattison 1980; Miller et al. 2000).

Removal of western juniper by mechanical treatment is a common restoration practice applied to late successional and fully developed woodlands because these stands no longer possess sufficient understory fuel loads to apply prescribed fire (Miller et al. 2000). Chainsaw cutting of juniper is annually applied to thousands of acres in eastern Oregon and has proven successful at increasing understory cover, productivity, forage quality, and diversity (Vaitkus and Eddleman 1987; Bates et al. 2000; Eddleman 2002).

Grazing of these plant communities by domestic livestock primarily occurs during the spring, summer, and/or fall seasons. However, there has been no applied research undertaken to evaluate grazing impacts on herbaceous recovery on treated juniper sites. Current grazing prescriptions following mechanical treatment of woodlands vary from several years of posttreatment rest to reintroducing livestock the first growing season after treatment. Introducing livestock too quickly after juniper cutting may inhibit perennial understory recovery, particularly on sites with a diminished perennial bunchgrass component, and may promote dominance by weedy annuals. However, treated juniper sites often account for only a small proportion of a pasture. Resting pastures for longer than 2 or more years may not be feasible for livestock managers, especially if longerterm rest or deferment interferes with other land management goals and objectives. Because the amount of woodlands treated has increased during the past decade, evaluating grazing impacts following juniper control is important for developing strategies that successfully restore or rehabilitate shrub-grassland plant communities in the northern Great Basin.

This study assessed plant community response after juniper cutting over a 4-year period. Grazing was applied the first 2 years after cutting. The objective of the study was to examine the influence of juniper cutting and livestock grazing on herbaceous cover, biomass, recruitment, and seed production. It was hypothesized that 1) cutting of juniper would result in increased herbaceous cover, biomass, density, and seed production compared to intact woodland; 2) cattle grazing of cut juniper woodland would delay understory response, therefore

${ }^{1}$ Nomenclature source: Hitchcock, C.L., and A. Cronquist. 1987. Flora of the Pacific Northwest. 6th printing. Seattle, WA: University of Washington Press. no differences in herbaceous response variables would be detected between grazed cut and grazed woodland treatments; 3) grazing of the cut treatment would suppress or delay herbaceous perennial establishment compared to the ungrazed cut woodland; and 4) cheatgrass cover and biomass would be greater on the grazed cut woodlands compared to the ungrazed cut treatment.

\section{MATERIALS AND METHODS}

\section{Site Description}

The study was located in a 125 -ha pasture on privately owned land on Steens Mountain, southeast Oregon. Elevation at the site is $1550 \mathrm{~m}$ and its aspect is west-facing with a $10^{\circ}$ slope. Juniper was dominant on about 50 ha of the pasture. The remainder of the pasture had scattered juniper with a basin big sagebrush-native bunchgrass understory. Treatments were applied within the juniper-dominated portion of the pasture. Juniper canopy cover averaged $27 \%$ and tree density averaged 231 trees $\cdot \mathrm{ha}^{-1}$ on the area selected for the study. Sagebrush had been competitively eliminated by juniper with only a scattering of old, decadent shrubs remaining. Bare ground covered $95 \%$ of the interspace. Sandberg's bluegrass (Poa sandbergii Vasey) was the dominant understory species, composing about $75 \%$ of total understory perennial plant cover. Other species on the site were bottlebrush squirreltail (Sitanion hystrix [Nutt.] Smith), bluebunch wheatgrass (Agropyron spicatum [Pursh] Scribn. \& Smith), Thurber's needlegrass (Stipa thurberiana Piper), basalt milkvetch (Astragalus filipes Torr.), and pale alyssum (Alyssum alyssoides L.). The climate is cool and moist during winter and spring, while summers are warm and dry. Annual precipitation (water year is September 1-August 30) at the Malheur National Wildlife Refuge, located $27 \mathrm{~km}$ northwest $(1250 \mathrm{~m})$ of the site, has averaged $265 \mathrm{~mm}$ over the past 44 years. Soils were described to the subgroup level and were predominately Typic Vitrixerand. Soils are underlain by a welded ash tuff of rhyolite-rhyodacite composition, which restricts root penetration at about $50 \mathrm{~cm}$.

\section{Experimental Design}

The experimental design was composed of 4 blocks containing 2 whole-plot grazing treatments (ungrazed and grazed) and 2 juniper subplot treatments (cut and uncut woodland) (Fig. 1). Treatments were ungrazed cut, grazed cut, ungrazed woodland, and grazed woodland. Four 1.8-ha blocks were established in the summer of 1998. Juniper cover and density, and herbaceous vegetation cover and density were characterized prior to tree cutting. One-half of each block was randomly selected for tree cutting. All juniper trees within cut plots were felled using chainsaws in September and October 1998. Felled juniper trees were left in place. A 4-strand barbed-wire fence was built through the center of the blocks in April 1999. Treatment plots were 0.45 ha in size. The west side (downslope of the fence) of each woodland and cut treatment replicate was grazed in 1999 and 2000, and the eastern side (upslope) was protected from domestic livestock grazing (refer to Fig. 1).

On the grazed treatment, livestock had access to and utilized a further 118 ha in the pasture. The prescription was to graze the field for a short duration in the spring when perennial 


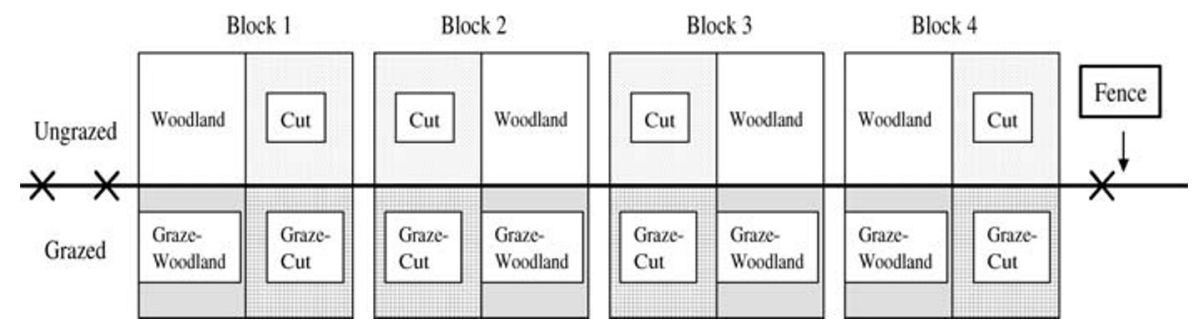

Figure 1. Experimental design for cutting and grazing treatments. Plots are 0.45 ha in size. The cutting treatment (fall 1998) was randomly assigned to half of each block. A 4-strand barbed-wire fence subdivided the blocks in 1999. Grazing occurred on west side of fence (downslope side) in 1999 and 2000. Cattle had unrestricted access to all grazed plots, thus grazing treatment lacks independence.

grasses were in vegetative growth stages. Stocking rates were 0.78 cow-calf pairs per ha for 5 days in early May 1999 and 0.94 cow-calf pairs per ha for 4 days in early May 2000. The short, intense grazing period differs from the typical grazing regime in the Great Basin, which is usually of light to moderate use for longer periods. The small size of the plots forestalled evaluation of a long period of light to moderate use. Retaining cattle for much longer than was prescribed would have resulted in repeated grazing of the cut treatment and nullified an objective of the grazing treatment, which was to permit grazed plants to regrow undisturbed for the balance of the growing season.

Removal of livestock was based on 1 of 2 criteria: 1 ) either $>$ $80 \%$ of the perennial grasses in the plots had been grazed (visually assessed as a percentage of individual plants grazed), or 2) phenology of Thurber's needlegrass had advanced to boot stage. Perennial grass growth in this system is most deleteriously affected by defoliation in the early boot stage (McIlvanie 1942; Blaisdell et al. 1953; Ganskopp 1988; Briske and Richards 1995). Plots were not grazed in 2001 and 2002 in order to quantify plant biomass and seed production response after grazing. Wildlife use was not quantified but was considered inconsequential.

\section{Understory Sampling}

Understory canopy cover and density measurements were collected each June from 1998 through 2002. Canopy cover by species; ground coverage with litter, bare ground, and rock; and perennial plant density were estimated inside $0.2-\mathrm{m}^{2}$ frames, spaced $3 \mathrm{~m}$ apart, along three $45-\mathrm{m}$ transects in both grazed and ungrazed portions of the cut and uncut woodlands. Juniper cover was measured along each transect by the line intercept method (Canfield 1941). Juniper density was estimated by counting all rooted individuals within $6-\times 45-\mathrm{m}$ belt transects. Sampling of herbaceous plants was not stratified by zone (intercanopy, canopy, or debris [downed juniper]).

Perennial grass seed production was measured in 2000 and 2001. Species sampled included Sandberg's bluegrass, bottlebrush squirreltail, Thurber's needlegrass, bluebunch wheatgrass, basin wildrye (Elymus cinereus Scribn. \& Merr.), Junegrass (Koeleria cristata Pers.), and Indian ricegrass (Oryzopsis hymenoides [R. \& S.] Ricker). The collection method consisted of hand-stripping ripe seed into paper bags twice per week from late June through early August. Seed production was estimated by collecting seed in 5 frames measuring $9 \mathrm{~m}^{2}$ in each treatment replicate. Subsamples for each species were handcleaned to estimate the percentage of filled seed. Seed was not tested for viability. Seed production was not measured in 1999 or 2002, as there was little reproductive development.

Grazing utilization of grasses (perennial and annual) and forbs (perennial and annual) was determined in 1999 and 2000, using methods described by Cassady (1941). Herbage was clipped to a $2-\mathrm{cm}$ stubble height the day before cattle were introduced and the day after cattle were removed from the field. Herbage was sampled at 5 -m intervals with $1-\mathrm{m}^{2}$ frames along three $45-\mathrm{m}$ randomly located transects in each treatment replicate. Clipped herbage was dried at $60^{\circ} \mathrm{C}$ for 48 hours prior to weighing.

Standing crop was determined in 2002. The sampling scheme was similar to 1999 and 2000 utilization measurements, except standing crop was sampled once in late June 2002 and was clipped by functional group. Functional groups were Sandberg's bluegrass, perennial bunchgrasses (e.g. Thurber's needlegrass, bluebunch wheatgrass, bottlebrush squirreltail), perennial forbs, cheatgrass, and annual forbs.

\section{Statistical Analysis and Data Presentation}

To compare the ungrazed woodland and ungrazed cut treatments, a repeated measures analysis for a randomized block design was used to assess year and treatment effects on herbaceous response variables (canopy cover, density, and seed production). The same procedure was used to compare grazed woodland and grazed cut treatments. Because grazed plots were not independent of each other (cattle had access to these plots simultaneously), and the study design was not randomized with respect to the ungrazed plots, the grazing treatment lacked true replication. Thus, herbaceous response variables for the grazed treatments (grazed cut and grazed woodland) were compared with ungrazed treatments using $t$ tests. Readers should note the lack of true replication in the grazed portion of the study, and take this into consideration when viewing the results. All statistical analyses were performed using the Statistical Analysis System (SAS Institute 2001). Data were tested for normality using the SAS univariate procedure (SAS Institute 2001). Data not normally distributed were log-transformed to stabilize 
Table 1. Precipitation data $(\mathrm{mm})$ from Malheur Wildlife Refuge, $25 \mathrm{~km}$ north of the study site. Data show water-year precipitation (September-August).

\begin{tabular}{|c|c|c|c|c|c|}
\hline Year & $\begin{array}{c}\text { Fall } \\
\text { (September- } \\
\text { November) }\end{array}$ & $\begin{array}{c}\text { Winter } \\
\text { (December- } \\
\text { February) }\end{array}$ & $\begin{array}{c}\text { Spring } \\
\text { (March- } \\
\text { May) }\end{array}$ & $\begin{array}{l}\text { Summer } \\
\text { (June- } \\
\text { August) }\end{array}$ & Annual \\
\hline \multicolumn{6}{|l|}{ Long-term } \\
\hline average & 60.8 & 70.9 & 74.4 & 47.2 & 253.2 \\
\hline 1998-1999 & 117.6 & 109.2 & 60.5 & 23.1 & 310.4 \\
\hline 1999-2000 & 11.4 & 88.7 & 57.2 & 6.4 & 163.6 \\
\hline 2000-2001 & 101.1 & 59.9 & 58.9 & 29.4 & 247.4 \\
\hline 2001-2002 & 48.5 & 70.6 & 50.5 & 32.5 & 202.2 \\
\hline
\end{tabular}

variance. Statistical significance of all tests was set at $P<0.05$. Unless noted, and to simplify data presentation, individual species results for cover, density, and standing crop were combined into the 5 functional groups or totaled.

\section{RESULTS AND DISCUSSION}

\section{Precipitation Patterns}

Precipitation (water year is September 1-August 30) in the first year after cutting (1998-1999) was 35\% greater than the longterm average (Table 1). Precipitation in the second (19992000 ) and fourth (2001-2002) years after cutting was 35\% and $20 \%$ below the long-term average. The third year following treatment (2000-2001) was considered average for total precipitation inputs. However, precipitation during the spring (March-May) was $24.4 \%$ below average (range $18.8 \%-$ $32.1 \%$ ) from 1999-2002.

\section{Ungrazed Cut Compared to Ungrazed Woodland}

Juniper cutting resulted in significant differences in herbaceous response between the ungrazed cut treatment and ungrazed

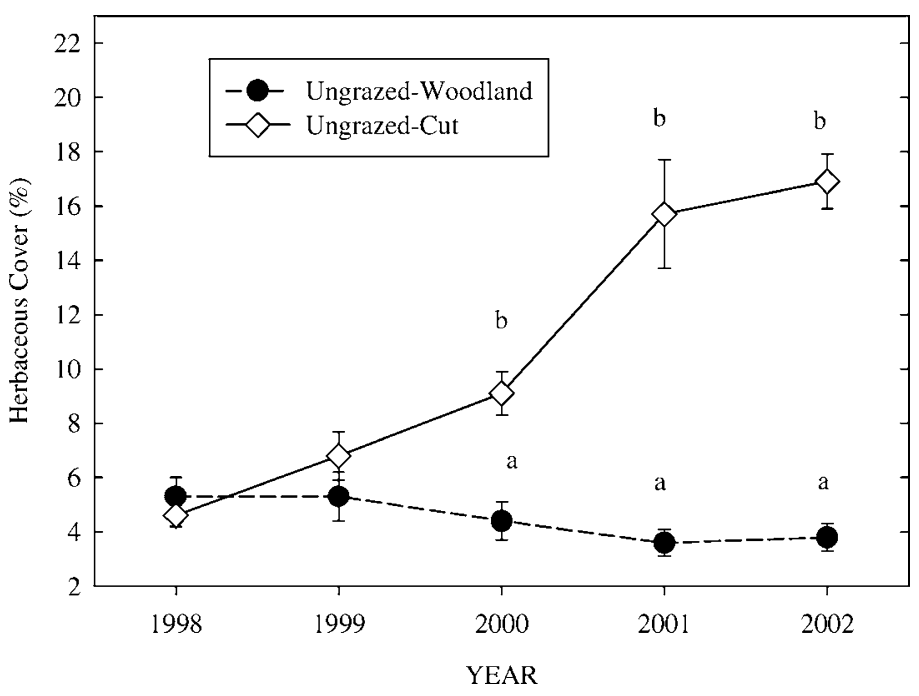

Figure 2. Herbaceous cover (\%) for ungrazed cut and ungrazed woodland treatments. Values are means $\pm 1 \mathrm{SE}$. Different lowercase letters indicate significant differences between treatments within year $(P<0.05)$.
Table 2. Density (plants $\cdot \mathrm{m}^{-2}$ ) values for perennial grasses and forbs in the ungrazed cut and ungrazed woodland treatments. Measured each June from 1998 through $2002^{1}$.

\begin{tabular}{lccc}
\hline Treatment & $\begin{array}{c}\text { Sandberg's } \\
\text { Bluegrass }\end{array}$ & $\begin{array}{c}\text { Large Perennial } \\
\text { Grasses }\end{array}$ & $\begin{array}{c}\text { Perennial } \\
\text { Forbs }\end{array}$ \\
\hline 1998 & & & \\
$\quad$ Ungrazed cut & $7.5 \pm 1.5$ & $2.5 \pm 0.7$ & $0.5 \pm 0.4$ \\
$\quad$ Ungrazed woodland & $8.9 \pm 0.9$ & $2.4 \pm 0.6$ & $1.0 \pm 0.2$ \\
1999 & & & \\
Ungrazed cut & $5.2 \pm 1.3$ & $2.7 \pm 0.8$ & $1.4 \pm 0.4$ \\
Ungrazed woodland & $7.9 \pm 0.6$ & $2.5 \pm 0.7$ & $1.4 \pm 0.4$ \\
2000 & & & \\
Ungrazed cut & $4.1 \pm 0.8 \mathrm{a}$ & $2.7 \pm 0.6$ & $1.8 \pm 0.5$ \\
$\quad$ Ungrazed woodland & $7.0 \pm 1.0 \mathrm{~b}$ & $1.4 \pm 0.6$ & $0.8 \pm 0.1$ \\
2001 & & & \\
$\quad$ Ungrazed cut & $4.8 \pm 1.2$ & $2.6 \pm 0.4$ & $2.4 \pm 0.9$ \\
$\quad$ Ungrazed woodland & $5.4 \pm 0.8$ & $1.6 \pm 0.6$ & $1.5 \pm 0.6$ \\
2002 & & & \\
Ungrazed cut & $4.9 \pm 1.3$ & $2.9 \pm 0.3 \mathrm{~b}$ & $2.1 \pm 0.6 \mathrm{~b}$ \\
Ungrazed woodland & $5.8 \pm 1.0$ & $1.7 \pm 0.5 \mathrm{a}$ & $0.7 \pm 0.3 \mathrm{a}$ \\
\hline
\end{tabular}

${ }^{1}$ Different lowercase letters indicate significant differences between treatment means by functional group within year $(P<0.05)$.

woodland. Cover, seed production, and standing crop all increased following cutting. Treatment and year interactions were significant for herbaceous canopy cover and perennial grass density. Canopy cover did not differ between the treatments until the second year postcutting, after which cover was greater in the ungrazed cut than in the ungrazed woodland (Fig. 2). By the fourth year postcutting (2002), herbaceous canopy cover was 4.5 times greater in the ungrazed cut than the ungrazed woodland (Fig. 2). Densities of large perennial grasses and perennial forbs did not differ between the treatments until the fourth year after treatment, when they were greater in the ungrazed cut than in the ungrazed woodland (Table 2). Differences in perennial grass density primarily resulted from a decline in density in the ungrazed woodland because perennial grass density did not increase in the ungrazed cut treatment.

In both measurement years, perennial grass seed production was significantly greater in the ungrazed cut than in the ungrazed woodland (Fig. 3). However, Sandberg's bluegrass seed production did not differ between the treatments. Total standing-crop biomass and functional-group biomass were significantly greater in the ungrazed cut $\left(277 \pm 77 \mathrm{~kg} \cdot \mathrm{ha}^{-1}\right)$ than in the ungrazed woodland $\left(68 \pm 14 \mathrm{~kg} \cdot \mathrm{ha}^{-1}\right)$ in 2002 .

Because juniper cutting resulted in a significant increase in herbaceous cover, standing crop, and seed production when compared to adjacent woodlands, the study's first hypothesis was accepted. In other western juniper and pinyon-juniper woodlands of the Great Basin, 2- to 10-fold increases in herbaceous biomass and 2- to 6-fold increases in herbaceous cover have been documented after woodland control (Everett and Sharrow 1985a; Young et al. 1985; Vaitkus and Eddleman 1987; Clary 1987; Rose and Eddleman 1994; Bates et al. 2000). 


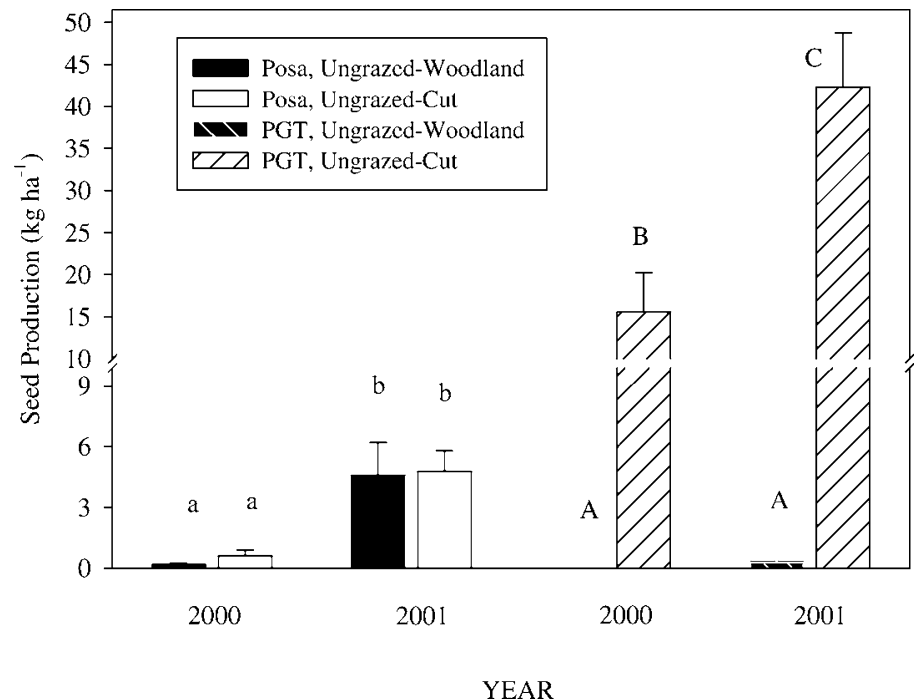

Figure 3. Comparison of seed production $\left(\mathrm{kg} \cdot \mathrm{ha}^{-1}\right)$ for Sandberg's bluegrass (Posa) and perennial grasses (PGT) in ungrazed cut and ungrazed woodland treatments. Values are means +1 SE. Different lowercase letters indicate significant differences for Posa between treatments and across years $(P<0.05)$. Different uppercase letters indicate significant differences for PGT between treatments and across years $(P<0.05)$.

Bates et al. (2000) and Everett and Sharrow (1985b) found that increased understory productivity following juniper removal was a result of greater availability of soil water and nitrogen. In the present study, soil water and available nitrogen were not measured but the greater understory productivity and higher cover in the ungrazed cut indicate that water and soil nutrients were more available for herbaceous plant uptake than in the ungrazed woodland.

Nonetheless, below-average precipitation slowed postcutting plant response. Except for the first growing season after cutting, annual precipitation was at or below average through the trials (Table 1). Because soils on the site are shallow and dry relatively quickly, average to above-average spring precipitation is required to produce rapid and substantial increases in herbaceous cover and biomass, and stimulate recruitment of high-seral perennial bunchgrasses (Bates et al. 1998; Bates et al. 1999; Bates et al. 2000). For example, in previous studies conducted on this site, herbaceous cover increased from 5\% to $28 \%$ and perennial grass density increased $300 \%$ by the fourth growing season after cutting (Bates et al. 1999). In this study, ground cover only increased from $5 \%$ to $16 \%$ and perennial grass density increased only $40 \%$ by the fourth year after cutting.

\section{Grazed Cut Compared to Grazed Woodland}

Differences between the grazed cut and grazed woodland treatments were not detected until the second growing season after treatment. Beginning in 2000 (second year postcutting), total herbaceous canopy cover increased in the grazed cut and was greater than in the grazed woodland in each subsequent year (Fig. 4). By 2002, total herbaceous canopy cover in the grazed cut was 4.5 times greater than in the grazed woodland. Densities of deep-rooted perennial grasses were significantly

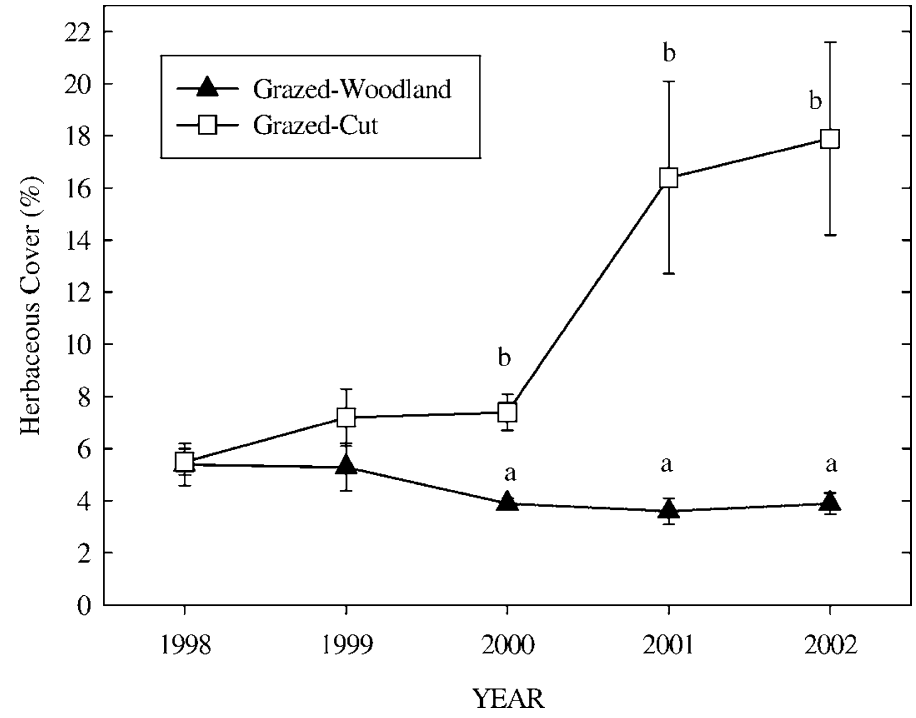

Figure 4. Herbaceous cover (\%) for grazed cut and grazed woodland treatments. Values are means $\pm 1 \mathrm{SE}$. Different lowercase letters indicate significant differences between treatments within year $(P<0.05)$.

greater in the grazed cut than in the grazed woodland treatment by 2002 (Table 3 ).

Grass utilization did not differ between cut and woodland treatments in the first year postcutting (1999), but did differ significantly in the second year postcutting (2000) (Fig. 5). In the grazed cut treatment, grass utilization was relatively uniform in both years and variability was low. Utilization of forbs was significantly greater on the grazed cut treatment than

Table 3. Density (plants $\cdot \mathrm{m}^{-2}$ ) values for perennial grasses and forbs in the grazed cut and grazed woodland treatments, measured each June from 1998 through $2002 .^{1}$

\begin{tabular}{lccc}
\hline Treatment & $\begin{array}{c}\text { Sandberg's } \\
\text { Bluegrass }\end{array}$ & $\begin{array}{c}\text { Large Perennial } \\
\text { Grasses }\end{array}$ & $\begin{array}{c}\text { Perennial } \\
\text { Forbs }\end{array}$ \\
\hline 1998 & & & \\
$\quad$ Grazed cut & $9.2 \pm 1.2$ & $2.2 \pm 0.4$ & $1.2 \pm 0.8$ \\
$\quad$ Grazed woodland & $8.3 \pm 1.0$ & $2.9 \pm 0.5$ & $1.5 \pm 0.1$ \\
1999 & & & \\
$\quad$ Grazed cut & $7.8 \pm 1.7$ & $2.5 \pm 0.2$ & $1.4 \pm 0.3$ \\
Grazed woodland & $7.3 \pm 0.9$ & $2.4 \pm 0.5$ & $1.6 \pm 0.2$ \\
2000 & & & \\
Grazed cut & $4.1 \pm 0.7$ & $1.9 \pm 0.3$ & $1.4 \pm 0.2$ \\
Grazed woodland & $6.9 \pm 0.9$ & $1.9 \pm 0.5$ & $1.2 \pm 0.3$ \\
2001 & & & \\
$\quad$ Grazed cut & $6.2 \pm 1.3$ & $3.3 \pm 0.5$ & $1.5 \pm 0.4$ \\
Grazed woodland & $6.0 \pm 0.9$ & $2.1 \pm 0.4$ & $0.6 \pm 0.3$ \\
2002 & & & \\
Grazed cut & $6.1 \pm 1.4$ & $3.5 \pm 0.5 \mathrm{~b}$ & $1.4 \pm 0.4 \mathrm{~b}$ \\
Grazed woodland & $5.8 \pm 0.6$ & $1.7 \pm 0.4 \mathrm{a}$ & $0.8 \pm 0.3 \mathrm{a}$ \\
\hline
\end{tabular}

${ }^{1}$ Different lowercase letters indicate significant differences between treatment means by functional group within year $(P<0.05)$. 


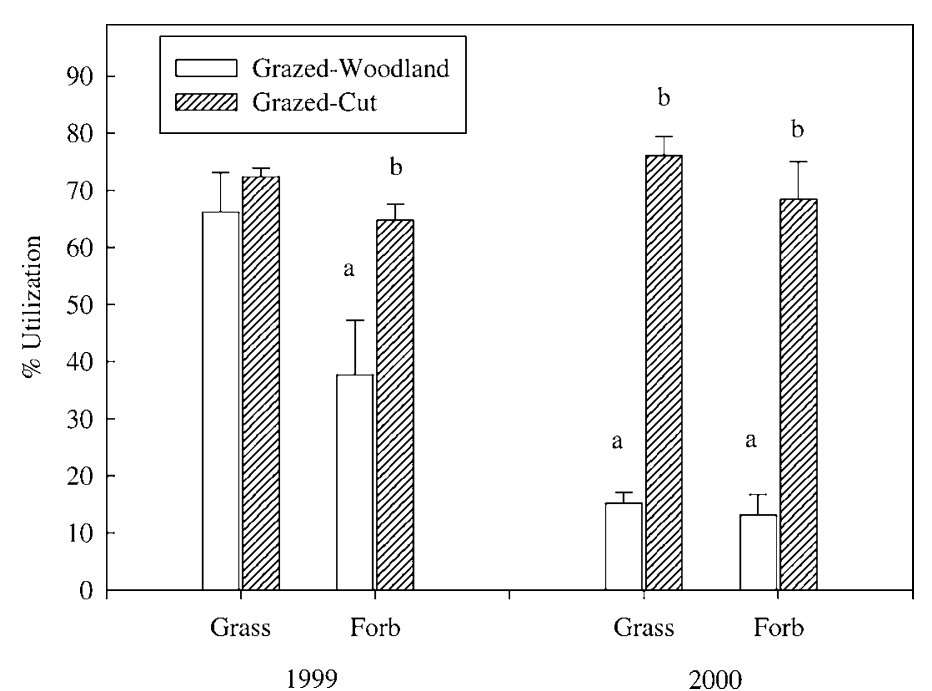

Figure 5. Grazing utilization for grass and forb groups in grazed cut and grazed woodland treatments. Values are means $+1 \mathrm{SE}$. Different lowercase letters denote significant differences $(P<0.05)$ between treatments within group by year.

in the grazed woodland in both years. In the grazed woodland, grass and forb utilization was significantly lower in 2000 than in 1999. It was observed that cattle tended to not enter grazed woodland plots in 2000, possibly because of the lack of available forage, which would explain the lower utilization levels in the woodland. Vegetative regrowth of perennial grasses was observed to occur only in the grazed cut after livestock were removed in 1999 and 2000.

Total standing crop was about 4 times greater in the grazed cut $\left(212 \pm 32 \mathrm{~kg} \cdot \mathrm{ha}^{-1}\right)$ than in the grazed woodland $\left(52 \pm 4 \mathrm{~kg} \cdot \mathrm{ha}^{-1}\right)$ in 2002. Functional-group standing crops were all significantly greater in the grazed cut than in the grazed woodland.

Sandberg's bluegrass seed production did not differ between the treatments in either year (Fig. 6). However, perennial grass seed production was significantly greater in the grazed cut than in the grazed woodland in both sample years. In the grazed woodland treatment, seed production in both collection years was primarily composed of Sandberg's bluegrass.

The experimental design prevented statistical comparison of all treatments simultaneously. However, the values and differences between the response variables for the grazed cut and the grazed woodland appeared to be similar to those measured between the ungrazed cut and ungrazed woodland treatments. This suggests that the removal of juniper interference has had a greater impact on site vegetation dynamics than did the grazing application. Because there were significant differences in herbaceous response between the grazed cut and grazed woodland treatments, the study's second hypothesis was rejected. This response may have resulted from the nature of the grazing treatment. Utilization was heavy in the grazed cut in both years. However, the grazing prescription was of short duration (4-5 days) and occurred in the spring when soil water content was adequate to allow understory plants to regrow almost immediately after livestock were removed in the grazed cut treatment. In the grazed woodland, herbaceous regrowth was not observed following livestock removal.

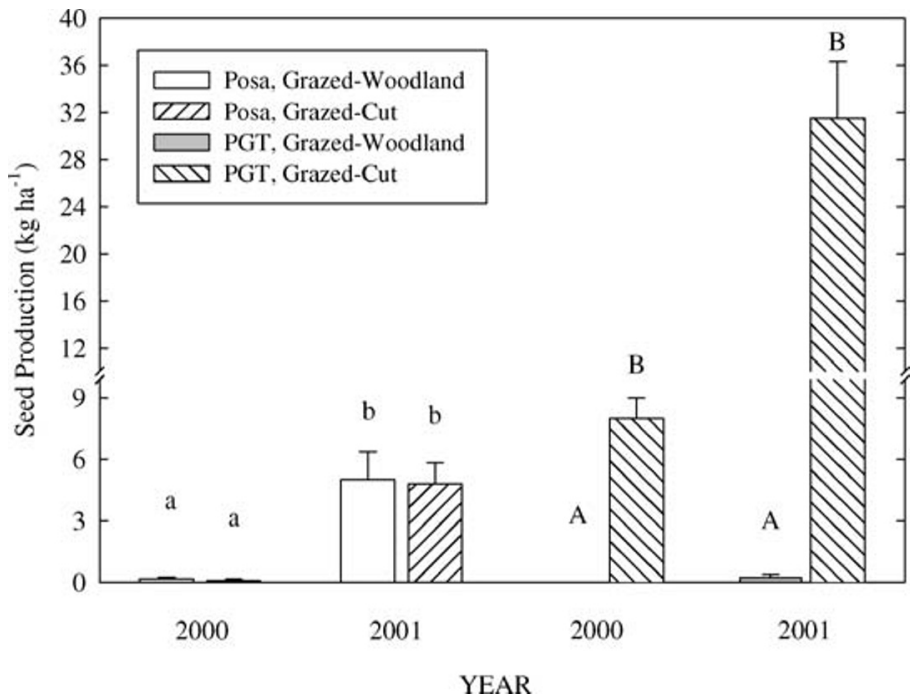

Figure 6. Comparison of seed production $\left(\mathrm{kg} \cdot \mathrm{ha}^{-1}\right)$ for Sandberg's bluegrass (Posa) and perennial grasses (PGT) in grazed cut and grazed woodland treatments. Values are means $+1 \mathrm{SE}$. Different lowercase letters indicate significant differences for Posa between treatments $(P<0.05)$. Different uppercase letters indicate significant differences for PGT between treatments $(P<0.05)$.

\section{Comparing Grazing Effects in Cut Areas}

Canopy cover, litter cover, and bare ground did not differ between ungrazed cut and grazed cut treatments in any year of the study (Table 4). Densities of large perennial grasses and forbs, though increasing slightly in the ungrazed cut and grazed cut treatments, did not differ between treatments during the study $(P>0.05)$. Grazing had little long-term impact on standing-crop biomass except for the large perennial grass group, which was greater in the ungrazed cut than in the grazed cut treatment (Fig. 7). This difference was attributed to the accumulation of litter within the grass bunches between 1999 and 2002 in the ungrazed cut treatment. The lack of differences in herbaceous response variables between ungrazed cut and grazed cut treatments resulted in the rejection of the study's third hypothesis.

Aside from cheatgrass, there was little recruitment of new plants in the ungrazed cut and grazed cut treatments. The increases in cheatgrass cover (Table 4) and standing crop (Fig. 7) developed similarly in both treatments, thus rejecting the study's fourth hypotheses. No increase in cheatgrass was associated with the grazing prescription after cutting. It was further observed that the increase in cheatgrass primarily took place under felled juniper trees and in the old litter horizons surrounding the stumps.

The short grazing prescription imposed prior to boot stage was detrimental to seed production on the grazed cut when compared to the ungrazed cut treatment, particularly in 2000, the last year the site was grazed (Fig. 8). Measurements in 2001 demonstrated that the grazed cut made a relatively quick recovery in seed production the first growing season after grazing was suspended, though production was still less than in the ungrazed cut. Thurber's needlegrass seed production appears to have been more sensitive to the grazing treatment in the cut woodlands than were other bunchgrass 
Table 4. Comparison of herbaceous functional-group canopy covers, bare ground and rock, and litter (\%) on ungrazed cut and grazed cut treatments, collected on Steens Mountain, Oregon. ${ }^{1}$

\begin{tabular}{|c|c|c|c|c|c|c|c|}
\hline \multirow[b]{2}{*}{ Treatment } & \multirow{2}{*}{$\begin{array}{c}\text { Sandberg's } \\
\text { Bluegrass }\end{array}$} & \multirow{2}{*}{$\begin{array}{l}\text { Large Perennial } \\
\text { Grass }\end{array}$} & \multicolumn{2}{|l|}{ Perennial } & \multicolumn{3}{|c|}{ Bare Ground } \\
\hline & & & Forb & Cheatgrass & Annual Forb & \& Rock & Litter $^{2}$ \\
\hline \multicolumn{8}{|c|}{ 1998-Pretreatment } \\
\hline Ungrazed cut & $2.0 \pm 0.5$ & $0.7 \pm 0.2$ & $0.3 \pm 0.1$ & $0.4 \pm 0.3$ & $1.2 \pm 0.2$ & $67.5 \pm 4.5$ & $27.8 \pm 4.1$ \\
\hline Grazed cut & $2.4 \pm 0.2$ & $1.0 \pm 0.2$ & $0.6 \pm 0.2$ & $0.2 \pm 0.1$ & $1.2 \pm 0.2$ & $64.9 \pm 3.9$ & $29.5 \pm 2.6$ \\
\hline \multicolumn{8}{|l|}{2000} \\
\hline Ungrazed cut & $1.8 \pm 0.4$ & $2.3 \pm 0.8$ & $1.3 \pm 0.5$ & $0.9 \pm 0.3$ & $2.8 \pm 0.4$ & $55.1 \pm 2.8$ & $35.7 \pm 4.0$ \\
\hline Grazed cut & $1.0 \pm 0.2$ & $1.6 \pm 0.4$ & $0.4 \pm 0.1$ & $1.6 \pm 0.5$ & $3.0 \pm 0.2$ & $50.5 \pm 2.6$ & $41.8 \pm 3.1$ \\
\hline \multicolumn{8}{|l|}{2001} \\
\hline Ungrazed cut & $2.1 \pm 0.5$ & $2.9 \pm 0.5$ & $1.3 \pm 0.5$ & $7.1 \pm 2.0$ & $2.3 \pm 0.4$ & $53.7 \pm 3.2$ & $31.2 \pm 5.8$ \\
\hline Grazed cut & $2.3 \pm 0.3$ & $2.2 \pm 0.2$ & $0.5 \pm 0.2$ & $9.4 \pm 3.3$ & $2.1 \pm 0.6$ & $51.9 \pm 1.3$ & $32.4 \pm 2.6$ \\
\hline \multicolumn{8}{|l|}{2002} \\
\hline Ungrazed cut & $1.9 \pm 0.2$ & $3.6 \pm 0.6$ & $1.4 \pm 0.5$ & $8.3 \pm 1.9$ & $1.7 \pm 0.4$ & $54.1 \pm 2.3$ & $30.3 \pm 4.1$ \\
\hline Grazed cut & $2.2 \pm 0.3$ & $2.6 \pm 0.3$ & $0.6 \pm 0.1$ & $10.1 \pm 3.1$ & $2.4 \pm 0.5$ & $51.2 \pm 1.2$ & $32.1 \pm 2.3$ \\
\hline
\end{tabular}

${ }^{1}$ Different lowercase letters indicate significant differences between treatment means within a column $(P<0.05)$ using $t$-tests.

${ }^{2}$ Litter includes old litter mat that existed under former trees and litter from downed trees.

species. How these differences in seed production may affect further site recovery can only be determined through continued monitoring.

Apart from affecting perennial grass seed production, cattle grazing after cutting did not limit herbaceous recovery during the relatively dry years coinciding with the study. Lack of a grazing effect may have resulted from one or more factors. First, the drought conditions may have masked any impacts that grazing had on herbaceous response in the cut treatment. With higher winter and/or spring precipitation, differences between the ungrazed cut and grazed cut prescriptions in herbaceous cover and density response may have become more apparent. Based on previous results reported for this community (Bates et al. 1998, 1999, and 2000), it was clear that herbaceous response was suppressed by the drought. Second, the grazing prescription imposed did not occur at a critical growth stage for herbaceous plants present. The grazing prescription was timed to occur during vegetative growth of Thurber's needlegrass, the main perennial grass growing on site. As observed, this permitted plants to begin regrowth from existing tillers within a few days after livestock were removed. If grazing had occurred later, while plants were in the boot stage, thus removing apical and intercalary meristems, regrowth response, especially during drought, would likely have been reduced. Grazing of bunchgrasses in boot stage requires growth reinitiation from axillary buds, which delays regrowth response of perennial bunchgrasses (Briske and Richards 1995) and reduces plant productivity and tillering in subsequent growing seasons (Blaisdell et al. 1953; Ganskopp 1988; Jirik and Bunting 1994). A third factor may have been the slope position of the ungrazed cut and grazed cut treatments. The grazed cut treatment was downslope of the ungrazed cut in all cases, and thus, may have accumulated more moisture as a result of runoff or subsurface water movement. If soil water availability was greater in the downslope position, this potentially could have counterbalanced any grazing-associated negative effects on herbaceous plants.

\section{CONCLUSIONS AND MANAGEMENT IMPLICATIONS}

Many studies, including this one, have shown that when western juniper is cut herbaceous plants will respond to the release from juniper interference with increased growth and productivity. However, the speed of herbaceous recovery is sensitive to posttreatment weather conditions. Because of drought, herbaceous response in this study was slower after juniper cutting than was measured in other juniper removal

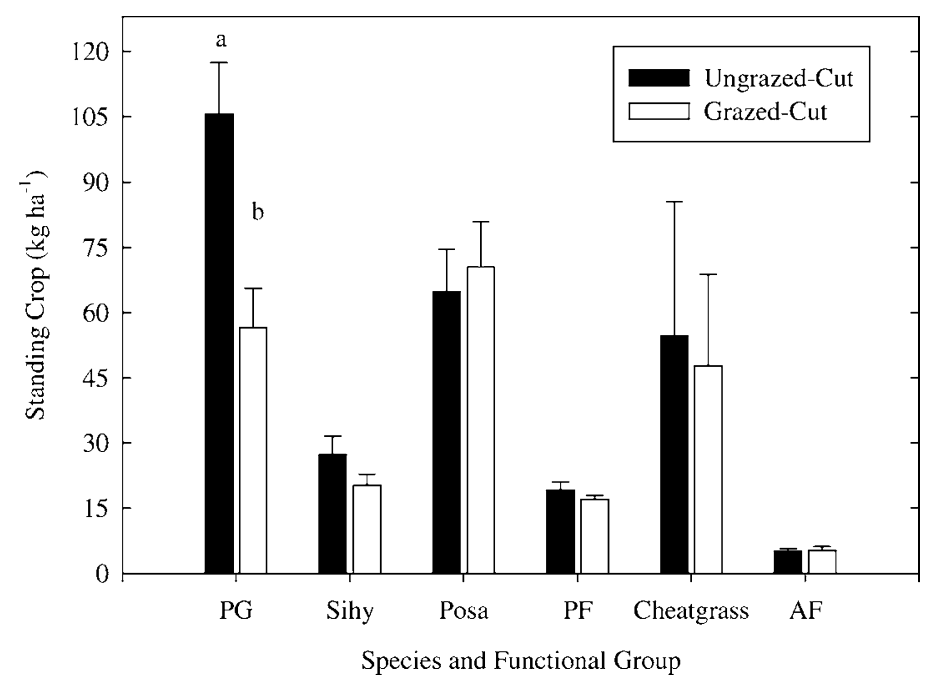

Figure 7. Functional-group standing crop $\left(\mathrm{kg} \cdot \mathrm{ha}^{-1}\right)$ comparisons for ungrazed cut and grazed cut treatments collected in June 2002 on Steens Mountain, Oregon. Response variables are perennial grasses (PG, e.g. bluebunch wheatgrass, Thurber's needlegrass, June grass), Siny (bottlebrush squirreltail), Posa (Sandberg's bluegrass), PF (perennial forbs), cheatgrass, and AF (annual forbs). Values are means +1 SE. Different lowercase letters indicate significant differences between ungrazed cut and grazed cut treatments $(P<0.05)$. 


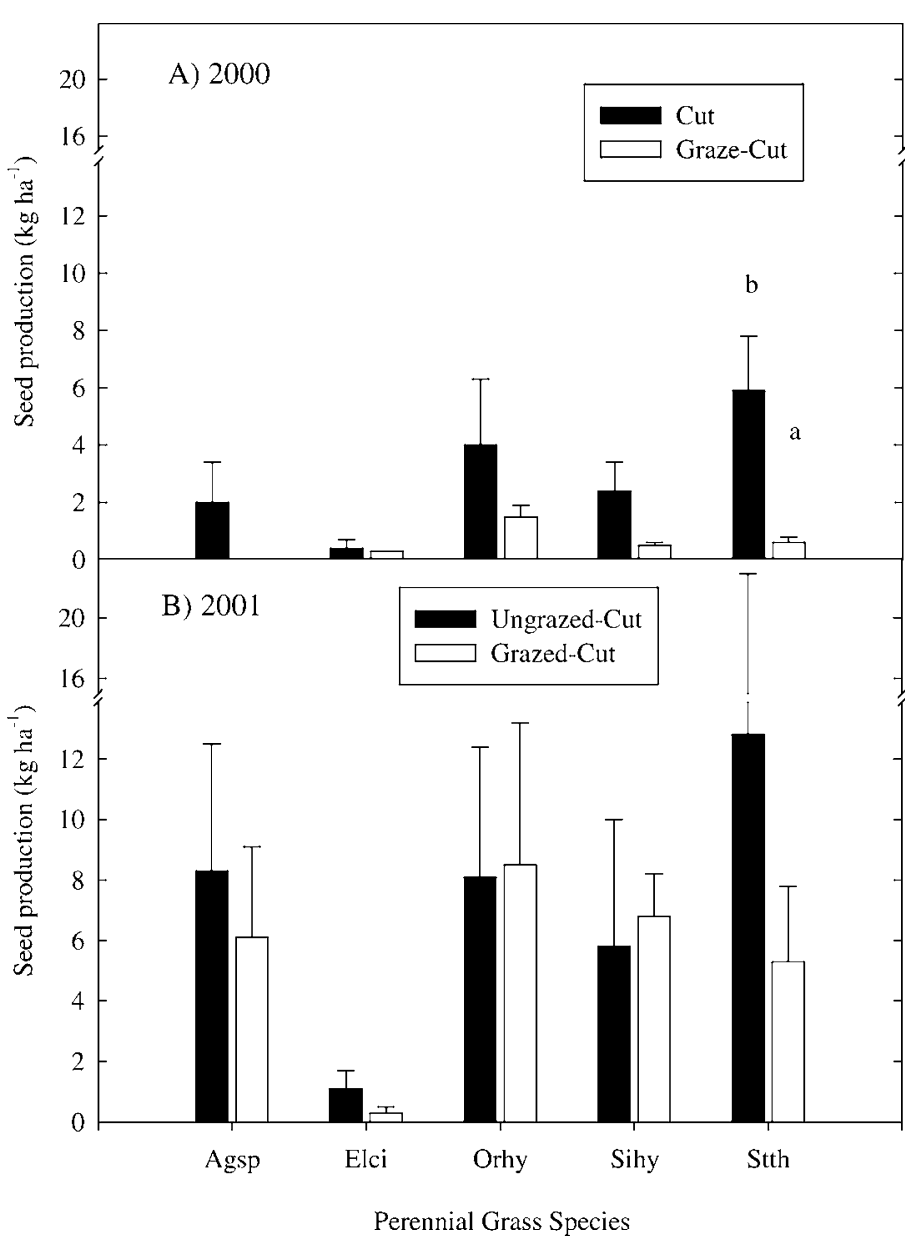

Figure 8. Comparison of seed production $\left(\mathrm{kg} \cdot \mathrm{ha}^{-1}\right)$ for perennial grass species in ungrazed cut and grazed cut treatments in 2000 and 2001. Response variables are Agsp (bluebunch wheatgrass), Elci (basin wildrye), Orhy (Indian ricegrass), Sihy (bottlebrush squirreltail), and Stth (Thurber's needlegrass). Values are means $+1 \mathrm{SE}$. Different lowercase letters indicate significant differences between treatments within year $(P<0.05)$.

studies conducted in the northern Great Basin sagebrushsteppe ecosystem.

Because of variability in site characteristics (plant community type, woodland successional stage, and soils), weather, and type and intensity of control method, no single grazing prescription can be applied with the expectation of successful site restoration. However, the primary goal remains the same when grazing treated areas, and that is to permit recovery of the ecological functions (hydrologic function, and energy and resource capture) of a site (Eddleman 1999). In Great Basin plant communities this is best achieved by restoring the system to one dominated by perennial grasses, forbs, and shrubs. Therefore, grazing management following juniper control should be adaptive to changing environmental and resource conditions, and will require constant reassessment to achieve short- and long-term restoration goals.

In the short term, this necessitates permitting existing plants on site to grow and produce viable seed. Significant seed production, as measured in this study, did not take place until the second and third years after juniper control. Thus, in the short term, treated sites require rest or deferment for the first several growing seasons if the objective is to maximize perennial grass seed crops. Longer-term considerations require that treated sites be managed to permit germination and establishment of new and desired individuals from seed crops produced during early succession.

\section{ACKNOWLEDGMENTS}

The author is grateful to Otley Brothers, Inc. for providing land, assisting in fence construction, and providing livestock for this study. Thanks to Tony Svejcar and Dave Ganskopp, USDA-ARS, and Dave Bohnert, Oregon State University, for assistance in collecting utilization samples. Many thanks to student summer range technicians for assistance in collecting cover, density, and biomass samples. Bruce Mackey, statistician at USDAARS, Albany, California, was greatly appreciated for all his statistical assistance.

\section{LITERATURE CITED}

Bates, J., R. F. Miller, and T. J. Svejcar. 1998. Understory patterns in cut western juniper (Juniperus occidentalis spp. occidentalis Hook.) woodlands. Great Basin Naturalist 58:363-375.

Bates, J., R. F. Miller, and T. J. Svejcar. 1999. Plant succession in cut juniper woodlands; 1991-98. In: Range field day 1999, juniper woodlands: History, ecology, and management. Special Report 1002. Corvallis, OR: Eastern Oregon Agricultural Research Center and Department of Rangeland Resources, Oregon State, University. p 30-43.

Bates, J. D., R. F. Miller, and T. J. SveJcAR. 2000. Understory vegetation response following cutting of western juniper. Journal of Range Management 53: 119-126.

BlaisdelL, J. P., A. C. Wiese, AND C. W. Hodgson. 1953. Effects of herbage removal at various dates on vigor of bluebunch wheatgrass and arrowleaf balsamroot. Ecology 30:298-305.

Briske, D. D., AND J. H. Richards. 1995. Plant responses to defoliation: a physiological, morphological, and demographic evaluation. In: D. J. Bedunah and R. E. Sosebee [eds]. Wildland plants: Physiological ecology and development morphology. Lakewood, CO: Society for Range Management. $p$ $635-710$.

Buckhouse, J. C., AND J. L. Mattison. 1980. Potential soil erosion of selected habitat types in the high desert region of central Oregon. Journal of Range Management 33:282-285.

Canfield, R. H. 1941. Application of the line interception method in sampling range vegetation. Journal of Forestry 39:388-394.

CASSADY, J. T. 1941. A method for determining range forage utilization by sheep. Journal of Forage 39:667-671.

CLARY, W. P. 1987. Herbage production and livestock grazing on pinyon-juniper woodlands. In: R.L. Everett [ed.]. Proceedings-Pinyon-juniper conference. 13-16 January 1986; Reno, NV. Ogden, UT: Intermountain Forest and Range Research Station, USDA-Forest Service General Technical Report, INT-215. p 440-447.

Eddleman, L. 1999. Ecological guidelines for management and restoration of pinyon and juniper woodlands. In: S.B. Monson and R. Stevens [compilers]. Proceedings: Ecology and management of pinyon-juniper communities within the interior West. 15-18 September 1997; Provo, UT. Ogden, UT: Rocky Mountain Research Station, USDA-Forest Service. Proceedings RMRS-P9. $p$ 366-370.

Everett, R. L., and S. H. Sharrow. 1985a. Response of grass species to tree harvesting in single leaf pinyon-Utah juniper stands. Ogden, UT: Intermountain Research Station, USDA-Forest Service. Paper INT-334. 7 p.

Everett, R. L., and S. H. Sharrow. 1985b. Soil water and temperature in harvested and nonharvested pinyon-juniper stands. Ogden, UT: Intermountain Research Station, USDA-Forest Service. Paper INT-342. 5 p. 
GanskopP, D. 1988. Defoliation of Thurber needlegrass: herbage and root response. Journal of Range Management 41:472-476.

JIRIK, S. J., AND S. C. Bunting. 1994. Post-fire defoliation response of Agropyron spicatum and Sitanion hystrix. International Journal of Wildland Fire 4: 77-82.

Mclivanie, S. K. 1942. Carbohydrate and nitrogen trends in bluebunch wheatgrass, Agropyron spicatum, with special reference to grazing influences. Plant Physiology 17:540-557.

Miller, R. F., and R. J. Tausch. 2001. The role of fire in juniper and pinyon woodlands: a descriptive analysis. In: K. E. M. Galley and T. P. Wilson [eds.]. Proceedings of the invasive species workshop: The role of fire in the control and spread of invasive species. Fire Conference 2000: The First National Congress on Fire Ecology, Prevention, and Management. 27 November1 December 2000; San Diego, CA. Tallahassee, FL: Tall Timbers Research Station. Misc. Pub. No.11. p 15-30.

Miller, R. F., T. J. Svejcar, and J. R. Rose. 2000. Impacts of western juniper on plant community composition and structure. Journal of Range Management 53:574-585.

MilleR, R. F., AND J. R. Rose. 1995. Historic expansion of Juniperus occidentalis southeastern Oregon. Great Basin Naturalist 55:37-45.

Rose, J. R., and L. E. Eddleman. 1994. Ponderosa pine and understory growth following western juniper removal. Northwest Science 68:79-85.

Vaitkus, M. R., and L. E. Eddleman. 1987. Composition and productivity of a western juniper understory and its response to canopy removal. In: R.L. Everett [ed.]. Proceedings-Pinyon-juniper conference. 13-16 January 1986; Reno, NV. Ogden, UT: Intermountain Forest and Range Research Station, USDA-Forest Service General Technical Report, INT-215. p 456-460.

Wall, T. G., R. F. Miller, and T. J. Svejcar. 2001. Juniper encroachment into aspen in the northwest Great Basin. Journal of Range Management 54: 691-698.

Young, J. A., R. A. Evans, and C. Rimby. 1985. Weed control and revegetation following western juniper control. Weed Science 33:513-517. 